\title{
Combination of strong anion exchange liquid chromatography with microchip capillary electrophoresis sodium dodecyl sulfate for rapid two-dimensional separations of complex protein mixtures
}

\author{
Holger Zagst ${ }^{1} \cdot$ Christin Elgert $^{2} \cdot$ Sönke Behrends ${ }^{2} \cdot$ Hermann Wätzig $^{1}$
}

Received: 26 May 2021 / Revised: 13 October 2021 / Accepted: 19 November 2021 / Published online: 6 December 2021

(c) The Author(s) 2021

\begin{abstract}
Two-dimensional separations provide a simple way to increase the resolution and peak capacity of complex protein separations. The feasibility of a recently developed instrumental approach for two-dimensional separations of proteins was evaluated. The approach is based on the general principle of two-dimensional gel electrophoresis. In the first dimension, semi-preparative strong anion exchange high-performance liquid chromatography is utilized and fractions are collected by means of a fraction collector. They are subsequently analyzed in the second dimension with microchip capillary electrophoresis sodium dodecyl sulfate. Microchip capillary electrophoresis provides the necessary speed (approximately $1 \mathrm{~min} /$ fraction) for short analysis. In this study, three different samples were investigated. Different constructs of soluble guanylyl cyclase were expressed in Sf9-cells using the baculovirus expression system. Cell lysates were analyzed and the resulting separations were compared. In our experimental setup, the soluble guanylyl cyclase was identified among hundreds of other proteins in these cell lysates, indicating its potential for screening, process control, or analysis. The results were validated by immunoblotting. Samples from Chinese hamster ovary cell culture before and after a purification step were investigated and approximately $9 \%$ less impurities could be observed. The separation patterns obtained for human plasma are closely similar to patterns obtained with two-dimensional gel electrophoresis and a total of 218 peaks could be observed. Overall, the approach was well applicable to all samples and, based on these results, further directions for improvements were identified.
\end{abstract}

Keywords Two-dimensional separation · Capillary electrophoresis sodium dodecyl sulfate $\cdot$ Anion exchange highperformance liquid chromatography $\cdot$ Protein analysis

\section{Introduction}

The use of multi-dimensional separations for complex samples is a proven and tested strategy to facilitate an improved separation and easier analysis of complex samples, which are often insufficiently resolved using only one separation technique [1]. In the last century, two-dimensional gel electrophoresis (2-DE) emerged as one of the most successful

Hermann Wätzig

h.waetzig@tu-bs.de

1 Technische Universität Braunschweig, Institute of Medicinal and Pharmaceutical Chemistry, Beethovenstraße 55, 38106 Braunschweig, Germany

2 Technische Universität Braunschweig, Institute of Pharmacology, Toxicology and Clinical Pharmacy, Mendelssohnstraße 1, 38106 Braunschweig, Germany technique for two-dimensional separations of complex protein mixtures [2].

With the advancement of analytical instruments, 2-DE has been replaced in many cases by automated instrumental approaches. Commonly employed strategies include high-performance liquid chromatography (HPLC) coupled to $(X)$ HPLC, capillary electrophoresis $(\mathrm{CE}) \times \mathrm{CE}$, and HPLC $\times$ CE approaches [3-8]. As pointed out by Ranjbar et al. [3], the popularity of HPLC $\times \mathrm{CE}$ is much lower than HPLC $\times$ HPLC, despite the high orthogonality that can be achieved $[3,4,6]$. Such combinations provide a unique selectivity and may offer an alternative to other approaches. Even though, both capillary electrophoresis sodium dodecyl sulfate (CE-SDS) and ion exchange chromatography (IEX) are frequently employed for the characterization of proteins [9-12], the coupling of both techniques has not received much attention [13]. 
Within our group, an HPLC $\times$ CE approach for the separation of protein mixtures has been recently developed [14, 15]. It is based on the general principle of 2-DE, that is, a charge-based separation in the first dimension followed by a size-based separation.

The charge-based separation in the first dimension is realized by strong anion exchange (SAX) HPLC. The employed stationary phase is based on a poly(styrene-divinylbenzene) polymer. It is stable over a wide $\mathrm{pH}$ and pressure range and compatible with many commonly found additives and buffer excipients. Furthermore, it has a high loading capacity [16, 17]. An RP-1 guard column protects the SAX column from lipophilic contaminants. Sample preparation is minimal and is usually limited to dilution and filtration. For a comprehensive offline coupling, the eluate is automatically collected in individual fractions by a fraction collector. The resulting fractions are subsequently analyzed by microchip capillary electrophoresis sodium dodecyl sulfate (MCE-SDS). The MCE-SDS system is compatible with common buffer additives used in IEX [18]. Another advantage of the chip-based assay is time expenditure. For each run in the first dimension, a manifold of runs is required in the second dimension. Therefore, the second dimension is often the speed-limiting step during analysis. Regular CE-SDS runs take about 15 to $35 \mathrm{~min}$, which is in the order of magnitude of a usual HPLC run. Therefore, several runs would represent a significant prolongation of an analysis. One possibility to circumvent this problem is the use of multiplexed capillary arrays [13]. In the presented approach, the chip-based separation is completed within $1 \mathrm{~min}$, effectively eliminating this issue.

Our approach is intended as a platform approach, applicable to a wide range of samples with minor method adaptions. In this study, three different samples were investigated.

A commonly used production system for recombinant proteins are Spodoptera frugiperda ( $\mathrm{Sf9}$ ) cells [19]. In our case, the Sf9 cells were used for the production of soluble guanylyl cyclase (sGC), a heterodimeric heme protein which is the main receptor for nitric oxide [20]. Cell lysates of transfected and untransfected cells were analyzed. The applicability of our approach for biotechnological process control or analysis was evaluated. The identification of the sGC and the general practicability were the main concern.

The supernatant obtained from a Chinese hamster ovary (CHO) cell culture sample and its intermediate after a protein A purification step were subjected to analysis by our approach. The cell culture produced an immunoglobulin G1 (IgG) monoclonal antibody (mAb), which was secreted into the surrounding medium. Besides the product, several other proteins, commonly referred to as host cell proteins (HCP), are secreted by the cells. The HCP amount is usually regarded as critical quality attribute and monitored closely. Its minimization is an important objective during downstream processing [21-24]. Several analytical methods are used for $\mathrm{HCP}$ characterization, each with individual strengths and weaknesses [21, 25, 26]. Our approach might serve as an alternative analytical technique for the comparison or optimization of purification steps or as an orthogonal technique for the HCP determination.

Human plasma is a well-controlled product with a consistent composition [27-30]. Its proteome is well characterized and many proteins serve as biomarkers in diagnostic applications [30-33]. The proteins, whose individual concentration can differ over several orders of magnitude [31], are embedded in a complex matrix consisting of lipids, ions, carbohydrates, and more [29, 30]. Therefore, human plasma represents an ideal model to compare various approaches.

The goal of this study is to demonstrate the feasibility and applicability of the approach.

\section{Material and methods}

\section{General}

Bovine serum albumin (BSA; Fraction V (pH 7.0) for Western blotting), dithiothreitol (DTT; BioChemica grade), ethylenediaminetetraacetic acid (EDTA; molecular biology grade), glycerol (molecular biology grade), and sodium chloride $(\mathrm{NaCl}$; for analysis) were obtained from PanReac AppliChem GmbH (Darmstadt, Germany). Sodium hydroxide $\left(\mathrm{NaOH}\right.$; EMSURE grade) and Amicon ${ }^{\circledR}$ Ultra0.5 Ultracel-10 K centrifugal filter devices were purchased from Merck (Darmstadt, Germany). Sodium chloride (HPLC grade) and 2-amino-2-(hydroxymethyl)propane-1,3-diol (TRIS; electrophoresis grade) were obtained from VWR International $\mathrm{GmbH}$ (Darmstadt, Germany) and exclusively used for the HPLC experiments. Hydrochloric acid ( $\mathrm{HCl}$, p.a. grade), albumin from human serum ( $\geq 97 \%$, HSA), albumin from chicken egg white ( $\geq 98 \%$, ovalbumin), bovine serum albumin ( $\geq 96 \%$, BSA), and $\beta$-lactoglobulin from bovine milk $(\geq 85 \%)$ were acquired from Sigma-Aldrich (Steinheim, Germany). Matuzumab was received as a gift from Merck KGaA (Darmstadt, Germany). Syringe filters (polyvinylidene fluoride, $0.22 \mu \mathrm{m}$ ) and $\beta$-mercaptoethanol ( $\beta$-ME, p.a. grade) were obtained from Carl Roth (Karlsruhe, Germany). Ultrapure water (conductivity $0.055 \mu \mathrm{S} / \mathrm{cm}$ ) was supplied by an arium ${ }^{\circledR}$ pro VF system from Sartorius (Goettingen, Germany). Nylon membrane filters $(0.2 \mu \mathrm{m}$ pore size, $47 \mathrm{~mm}$ diameter) were supplied by GE Healthcare (Buckinghamshire, UK). The centrifuges 5417C and 5430 were purchased from Eppendorf (Hamburg, Germany). The $\mathrm{pH}$ measurements were done with a FiveEasy ${ }^{\mathrm{TM}}$ FE20 $\mathrm{pH}$-meter and either an LE438 $\mathrm{pH}$ electrode (buffers) or an InLab Micro electrode (samples), all from Mettler Toledo (Gießen, Germany). All other chemicals were obtained from Sigma-Aldrich (Steinheim, Germany) in the highest grade of 
purity. Figures were plotted in OriginPro 2021 (9.8.0.200) from OriginLab Cooperation (Northampton, MA, USA). Calculations were performed using Microsoft ${ }^{\circledR}$ Excel ${ }^{\circledR}$ 2019 (v. 1809) from Microsoft Corporation (Redmond, WA, USA).

\section{HPLC system and fraction collector}

The HPLC system (dwell volume $7.6 \mathrm{~mL}$ ) consisted of a VWR Hitachi L-2130 quarternary pump, an L-2200 autosampler fitted with a $5.0 \mathrm{~mL}$ syringe kit, an L-2450 diodearray detector (all VWR International GmbH, Darmstadt, Germany), and a Techlab T1 column oven (Techlab, Braunschweig, Germany). The HPLC was controlled by EZChrom Elite (3.3.2 SP2, VWR International $\mathrm{GmbH}$ ) and it was further used for data handling and integration. Directly coupled to the system was a Foxy R1 fraction collector (Knauer, Berlin, Germany), whose control was integrated into the HPLC software. The stationary phase was a semi-preparative PLSAX $1000 \AA$, $8 \mu \mathrm{m}, 50 \times 7.5 \mathrm{~mm}$ column (Agilent Technologies, Waldbronn, Germany) protected by a $4 \times 3.0 \mathrm{~mm}$ RP- 1 guard column (Phenomenex, Aschaffenburg, Germany).

Mobile phase A (MPA) consisted of $20 \mathrm{mM}$ TRIS $\mathrm{pH}$ 8.5 , mobile phase $\mathrm{B}$ (MPB) consisted of $20 \mathrm{mM}$ TRIS and

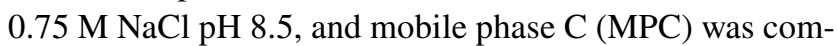
posed of $20 \mathrm{mM}$ TRIS and $1.5 \mathrm{M} \mathrm{NaCl} \mathrm{pH} \mathrm{8.5.} \mathrm{The} \mathrm{pH}$ was adjusted to \pm 0.05 units with $6 \mathrm{M} \mathrm{HCl}$. All mobile phases were filtered through nylon membrane filters prior to use. If not otherwise indicated, the following method parameters were used. The column oven was thermostated at $30{ }^{\circ} \mathrm{C}$, the flow rate was set to $1.3 \mathrm{~mL} / \mathrm{min}$, and UV absorption at $200 \mathrm{~nm}, 214 \mathrm{~nm}$, and $280 \mathrm{~nm}$ ( $4 \mathrm{~nm}$ bandwidth, $2.5 \mathrm{~Hz})$ was recorded. The injection volume is indicated at the respective samples. The following gradient was used for elution: from 0.0 to $5.0 \mathrm{~min} 100 \% \mathrm{MPA}$, followed by a linear gradient from $0 \%$ at $5.0 \mathrm{~min}$ to $100 \% \mathrm{MPB}$ at $45.0 \mathrm{~min}$. From 45.1 to $55.0 \mathrm{~min} 100 \% \mathrm{MPC}$ and from 55.1 to $70.0 \mathrm{~min} 100 \% \mathrm{MPA}$ was pumped through the system.

\section{MCE-SDS}

A LabChip ${ }^{\circledR}$ GX II Touch ${ }^{\mathrm{TM}}$ HT instrument, controlled with LabChip ${ }^{\circledR}$ GX Touch $^{\mathrm{TM}}$ software (v. 1.7.819.0), was used with Protein Express LabChips and associated Protein Express kits (all PerkinElmer, Waltham, MA, USA). The HT Protein Express 200 high sensitivity assay was used. The proprietary chips are made of fused silica with a footprint of $37.25 \mathrm{~mm} \times 37.25 \mathrm{~mm}$. A plastic case $(49.6 \mathrm{~mm} \times 49.6 \mathrm{~mm}$ footprint, height up to $14 \mathrm{~mm}$ ) is glued to the top of the chip and provides eight cylindrical wells for reagents and waste. A fused silica capillary (20-50 $\mu \mathrm{m}$ diameter, $24 \mathrm{~mm}$ length) is attached to the bottom of the chip as a "sipper" [34]. The "sipper" is used to hydrodynamically aspirate approximately
$100-150 \mathrm{~nL}$ of the sample. The sample is subsequently moved electrokinetically into the separation channel (length $14 \mathrm{~mm}$, width $31 \mu \mathrm{m})[35,36]$. A TRIS-Tricine buffer containing a non-cross-linked, linear, high molecular mass poly(dimethylmethacrylate) polymer, sodium dodecyl sulfate (SDS), and a proprietary dye is used as a sieving matrix for the size-based separation in an entangled polymer network at $30^{\circ} \mathrm{C}[36,37]$. Laser-induced fluorescence (excitation $635 \mathrm{~nm}$, emission $700 \mathrm{~nm}$ ) is utilized for detection [38]. Further information about the detailed mode of operation is given by Chow [36] and in the associated patent [37]. In the preceding publication by Bousse et al. [39], a field strength of 200-300 V/cm is employed for the separations. The data was evaluated with the LabChip ${ }^{\circledR}$ GX Reviewer software (v. 5.5.2312.0, PerkinElmer).

\section{Protein concentration}

Total protein concentrations were determined by the method of Bradford [40] using BSA as standard and Roti-Quant ${ }^{\circledR}$ (Carl Roth, Karlsruhe, Germany) as dye. Absorption at 470 and $595 \mathrm{~nm}$ was recorded by a Sunrise ${ }^{\mathrm{TM}}$ Absorbance Reader controlled and evaluated by Magellan ${ }^{\mathrm{TM}}$ software (both Tecan Deutschland GmbH, Crailsheim, Germany).

\section{Sample preparation}

\section{Sf9 cytosol lysate}

Sf9 cells were obtained from the DSMZ (German Collection of Microorganisms and Cell Culture, Braunschweig, Germany). Soluble guanylyl cyclase subunits were recombinantly expressed using the baculovirus/Sf 9 cell system. Recombinant viruses were generated as described in the Bac-to-Bac ${ }^{\circledR}$ Baculovirus Expression System manual [41] (Invitrogen $^{\mathrm{TM}}$, Thermo Fisher Scientific, Waltham, USA). Sf9 cells were cultivated in Sf-900 ${ }^{\mathrm{TM}}$ II Serum Free Medium (Gibco ${ }^{\circledR}$ by life technologies ${ }^{\mathrm{TM}}$, Thermo Fisher Scientific, Waltham, USA) supplemented with $10 \%$ fetal calf serum and $1 \%$ penicillin/streptomycin. Spinner cultures were grown at $27^{\circ} \mathrm{C}$ and $140 \mathrm{rpm}$ on a shaking incubator. For experiments, Sf9 cell density was adjusted to $2 \times 10^{6}$ cells $/ \mathrm{mL}$ and a volume of $100 \mathrm{~mL}$ was co-infected with baculoviruses encoding the sGC subunits: $\mathrm{N}$-terminally twin strep tagged (TST) $\alpha_{1}$ $[42,43]$ and $\beta_{1}[44]$ subunits. Fusion protein $\beta_{1} \mathrm{YFP} \alpha_{1}$ was cloned as previously described in [45]. Conjoined sGC $\beta_{1} \alpha_{1}$ fusion construct was cloned as described in [46].

After $72 \mathrm{~h}$ of incubation, Sf9 cells were harvested by centrifugation $\left(3020 \times g\right.$ at $4{ }^{\circ} \mathrm{C}$ for $\left.2 \mathrm{~min}\right)$. The cell pellet was resuspended in lysis buffer $(50 \mathrm{mM}$ triethanolamine/ $\mathrm{HCl}, 10 \mathrm{mM}$ DTT, 1 mM EDTA, pH 7.4) containing complete $^{\mathrm{TM}}$ protease inhibitor cocktail (Roche, Mannheim, Germany) and homogenized by ultrasound sonication. The 
samples were cleared by centrifugation $\left(21,000 \times g\right.$ at $4{ }^{\circ} \mathrm{C}$ for $30 \mathrm{~min})$. The cell lysates were diluted with MPA $(1+1)$ and filtered through syringe filters. Injection volume was adjusted to the determined protein content so the injected protein amount remained comparable.

\section{Samples from $\mathrm{CHO}$ cell culture containing an lgG antibody}

Cell culture supernatant and protein A purified IgG antibody, derived from a fed batch of a ready-to-use biosimilar $\mathrm{CHO}$ cell line using First $\mathrm{CHOice} \circledast$ medium and feeds, were kindly provided by UGA Biopharma GmbH (Hennigsdorf, Germany). The frozen $\left(-20^{\circ} \mathrm{C}\right)$ samples were thawed, vortexed (15 s), diluted with MPA $(1+1)$, and filtered through syringe filters.

\section{Fresh-frozen human plasma}

Anonymized leukocyte-depleted fresh-frozen human plasma was obtained from Städtisches Klinikum Braunschweig $\mathrm{gGmbH}$ and stored at $-32^{\circ} \mathrm{C}$. It was thawed in a tempered water-bath at $37^{\circ} \mathrm{C}$. The plasma was aliquoted and the aliquots were stored at $-32^{\circ} \mathrm{C}$. For use, aliquots were thawed as previously described and diluted with MPA $(1+1)$, vortexed for $15 \mathrm{~s}$, and filtered through syringe filters. Adjustments of the $\mathrm{pH}$ were done with $1 \% \mathrm{NaOH}$ before filtration.

\section{Fraction collection and preparation for MCE-SDS}

If not otherwise indicated, in each HPLC run, 30 fractions evenly spread over $45 \mathrm{~min}$ were collected (equals to $1.5 \mathrm{~min}$ or $1.95 \mathrm{~mL}$ per fraction). If the fractions were not processed immediately after collection, they were stored at $-20{ }^{\circ} \mathrm{C}$ and thawed for measurement. All fractions were vortexed $3 \times 5 \mathrm{~s}$ and centrifuged at $10,000 \times g$ for $3 \mathrm{~min}$. Then, samples were prepared according to the manufacturer's protocol [18]. Briefly, to $7 \mu \mathrm{L}$ of sample buffer containing 3.4\% $(\mathrm{V} / \mathrm{V}) \beta$-ME, $5 \mu \mathrm{L}$ of each fraction were added in a $96-$ well plate. For non-reduced conditions, the sample buffer was used without the addition of $\beta$-ME. The plate was sealed and heated to $100{ }^{\circ} \mathrm{C}$ for $5 \mathrm{~min}$. After cooling to room temperature, the plate was centrifuged at $1250 \times g$ for $5 \mathrm{~min}$; then, $32 \mu \mathrm{L}$ water were added and mixed thoroughly. The plate was centrifuged again at $1250 \times g$ for $5 \mathrm{~min}$; then, the samples were measured with the LabChip ${ }^{\circledR}$.

\section{Sodium dodecyl sulfate polyacrylamide gel electrophoresis (SDS-PAGE) and immunoblot analysis}

For desalting, $500 \mu \mathrm{L}$ from each sample's $21^{\text {st }}$ fraction were transferred to an Amicon® filter device. Each capped device was centrifuged at $14,000 \times g$ for $5 \mathrm{~min}$. Then, $250 \mu \mathrm{L}$ of MPA were added. Centrifugation at $14,000 \times g$ for $5 \mathrm{~min}$ followed. This was repeated three more times. Finally, MPA was added to an approximate volume of $250 \mu \mathrm{L}$, the filter device inverted, and the desalted concentrate recovered by centrifugation for $2 \mathrm{~min}$ at $2060 \times \mathrm{g}$.

SDS sample buffer (1\% SDS, $50 \mathrm{mM}$ TRIS/HCl, $100 \mathrm{mM}$ DTT, $30 \%$ glycerol, pH 7.5) was added to each sample (raw lysates and desalted fractions) in a 1:1 ratio. Samples were vortexed for homogenization and heated to $99{ }^{\circ} \mathrm{C}$ for $3 \mathrm{~min}$. After cooling, $80 \mu \mathrm{g}$ of total protein was separated on a $10 \%$ SDS polyacrylamide electrophoresis gel. SDS-PAGEs were performed on the Mini-PROTEAN® Tetra System by BioRad in a TRIS/glycine/SDS running buffer (25 mM TRIS, $192 \mathrm{mM}$ glycine, 0.1\% SDS, pH 8.3) and an applied voltage of $80 \mathrm{~V}$ for $4 \mathrm{~h}$. The apparent molecular masses were determined by using PageRuler ${ }^{\mathrm{TM}}$ Unstained Protein Ladder and PageRuler ${ }^{\mathrm{TM}}$ Prestained Protein Ladder (both from ThermoFisher Scientific, Waltham, USA). After completion of the electrophoresis, the gels were washed with deionized water and proteins were transferred to nitrocellulose membranes using the Semi-Dry electro blotter Sedec ${ }^{\mathrm{TM}}$ M (Peqlab Biotechnology, Erlangen) with transfer buffer (25 mM TRIS, 192 mM glycine, 0.02\% SDS, pH 8.3). Ponceau S staining, blocking of non-specific binding sites, and antibody incubation were performed as described in [45]. The following primary antibodies were used for detection: $\alpha_{1}$ (1:5000; Sigma-Aldrich G4280, Steinheim, Germany) and $\beta_{1}$ (1:2000; Sigma-Aldrich G4405, Steinheim, Germany). Anti-rabbit IgG horseradish peroxidase-linked antibody (1:2000; Cell-Signaling Technologies 7074, Danvers, MA, USA) was used as secondary antibody for detection.

\section{Results and discussion}

\section{Sf9 cytosol lysate}

\section{Two-dimensional separations}

The resulting two-dimensional separations of the three samples are shown in Fig. 1. The total protein concentrations of the samples before dilution were $49.6 \mathrm{mg} / \mathrm{mL}$ (untransfected), $24.8 \mathrm{mg} / \mathrm{mL}$ (transfected with $\mathrm{TST} \alpha_{1} / \beta_{1}$ ), and $26.2 \mathrm{mg} / \mathrm{mL}$ (transfected with fusion protein $\beta_{1} \alpha_{1}$ ). The Sf9 cytosol lysates show very similar peak patterns across all three samples. Most of the peaks were found in fraction 2 and 10 to 22 . The peaks are primarily found within the $10-100 \mathrm{kDa}$ range. The ever-present peak at approximately $7 \mathrm{kDa}$ is a system peak originating from SDS micelles. Most peaks were present in all samples, forming a characteristic peak pattern. There are some variations in their intensity, which is in accordance with the expectations, as the 

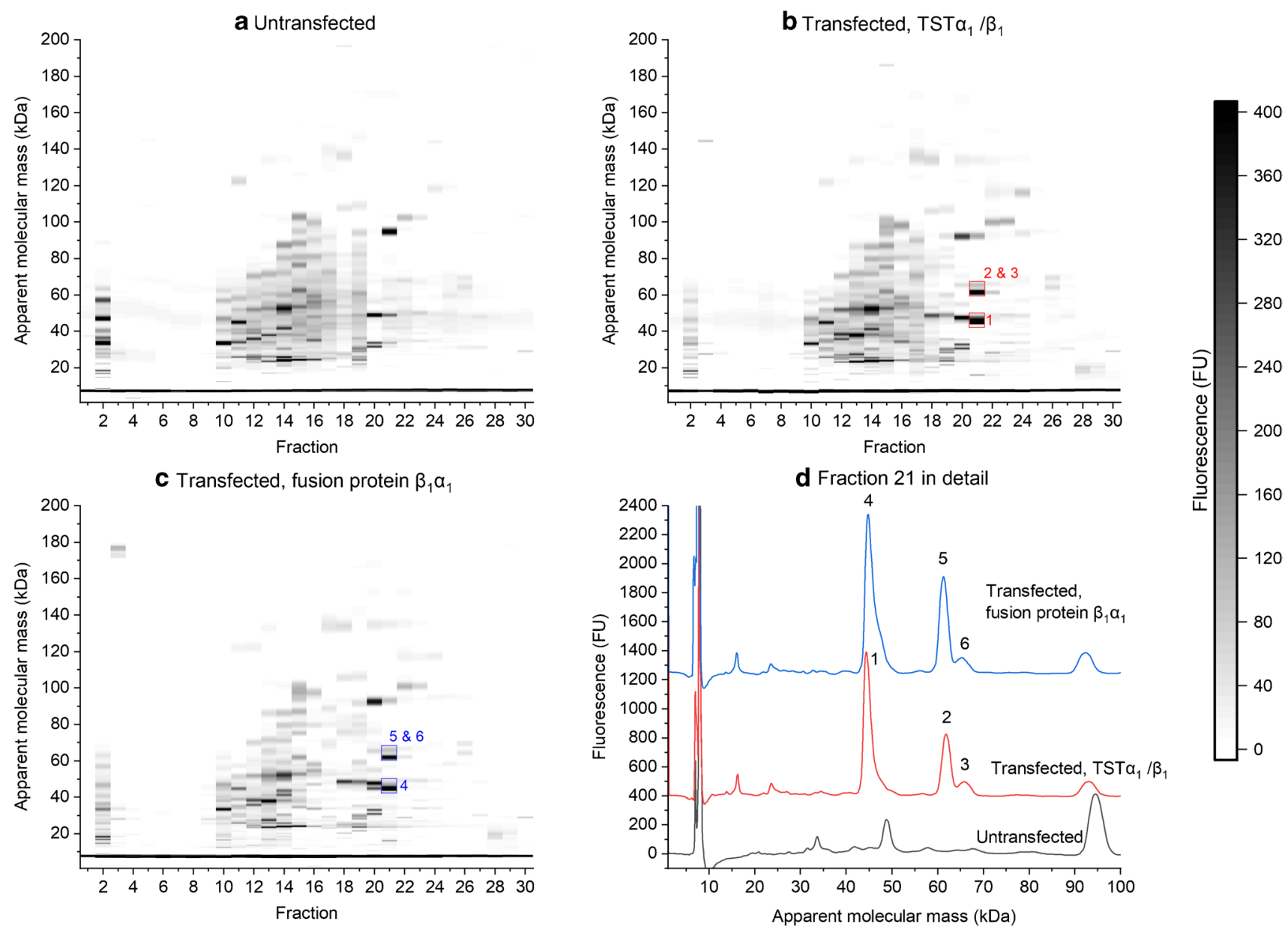

Fig. 1 Two-dimensional separations (reduced conditions) of Sf9 cytosol lysate from a untransfected cells, $750 \mu$ injected; b transfected cells expressing the sGC subunits TST $\alpha_{1}$ and $\beta_{1}, 1500 \mu \mathrm{L}$ injected; c transfected cells, expressing sGC fusion protein $\beta_{1} \alpha_{1}, 1423 \mu \mathrm{L}$ injected; $\mathbf{d}$ shows the individual electropherograms of the $21^{\text {st }}$ frac-

LabChip ${ }^{\circledR}$ assay has some variety [18]. Additionally, cells, as a living organism, have an inherent biological variety. The major difference between the samples was observed in fraction 21. Here, both transfected samples, but not the untransfected sample, clearly displayed a peak at $61 \mathrm{kDa}$ (Peak 2 in Fig. 1b/d) with a shoulder peak at $65 \mathrm{kDa}$ (Peak 3 in Fig. 1b/d). This difference corresponds to a differently shaped peak at approximately $30 \mathrm{~min}$ in the HPLC chromatogram for both transfected samples (SI Fig. 1). It is presumed that this peak pair in the electropherogram can be attributed to the $\alpha_{1}$ and $\beta_{1}$ subunit of the sGC with a molecular mass of approximately $77 \mathrm{kDa}$ and $70 \mathrm{kDa}$, respectively [47]. The assay's sizing accuracy is defined with $\pm 20 \%$ [18] and no major differences in this size range were found in other fractions, further reassuring this hypothesis. An additional peak at $44 \mathrm{kDa}$ (Peak 1 in Fig. 1b/d) is also noticeable. Surprisingly, the sample containing the fusion protein also showed peaks at 61 and $65 \mathrm{kDa}$ (Peaks 5 and 6 in Fig. 1c/d),

tion of each separation, bottom (black) untransfected sample, middle (red) transfected sample TST $\alpha_{1} / \beta_{1}$ (offset $400 \mathrm{FU}$ ), and top (blue) transfected fusion protein sample (offset $1250 \mathrm{FU}$ ); peaks 1-6 are attributed to the sGC

instead of one expected peak at around $150 \mathrm{kDa}$. The additional peak at $44 \mathrm{kDa}$ (Peak 4 in Fig. 1c/d) was also present. This indicates that the protein might be instable under the given conditions. The experiment was repeated to verify the results, albeit including cells expressing a slightly modified fusion construct, containing an additional tag $\left(\beta_{1} \mathrm{YFP} \alpha_{1}\right.$ [45]). As in the preceding experiment, a peak around $46 \mathrm{kDa}$ and peak pair at $61 \mathrm{kDa}$ and $65 \mathrm{kDa}$ could be observed in the $21^{\text {st }}$ fraction of each transfected samples, but not in the untransfected sample's fraction 21 (SI Fig. 2).

\section{Validation of peak identity}

Since these results still left some uncertainty about the peak identity, each sample's fraction 21 as well as the raw cell lysates were separated by SDS-PAGE and subsequently analyzed by immunoblotting. The $\alpha_{1}$ and $\beta_{1}$ subunits were found in all lysates from transfected cells and in every 
corresponding 21st fraction. All untransfected samples were devoid of these two proteins (Fig. 2). The fractions containing the fusion protein display bands for the $\beta_{1}$ subunit not only around $150 \mathrm{kDa}$, but also slightly above $70 \mathrm{kDa}$. The corresponding samples with the raw cytosol display the same bands (Fig. 2b). Similar results were obtained for the $\alpha_{1}$ subunit; however, the samples containing the fusion protein only had a minor band at the expected position of the individual $\alpha_{1}$ subunit (Fig. 2a). Based on practical experience with the $\alpha_{1}$ subunit, it appears to be less stable than the $\beta_{1}$ subunit. The observed instability of the fusion protein might be the result of protein degradation, including the separation into the respective subunits. Since the observed instability applies to all samples, raw material, and individual fractions, it is most likely not limited to our method, but its conditions seem to amplify the degradation, especially in the case of the fusion protein. Overall, these findings support the observations of the two-dimensional separations and offer a reasonable explanation for them. The results could be confirmed using the raw lysates and corresponding $21^{\text {st }}$ fraction from the repeated experiment containing the $\beta_{1} \mathrm{YFP}_{1}$ fusion protein (SI Fig. 3).

Commonly, the peak identity is confirmed by mass spectrometry (MS) [4, 48-50]. MCE-SDS and CE-SDS in general are considered as incompatible with MS due to the intrinsic properties of the employed gel matrix. Nevertheless, approaches to address this issue have been published [51-53], with the most recent one [51] showing promising results. These approaches are currently limited to regular CE-SDS and do not include chip-based formats. However, recent progresses in microchip-based CIEF-MS [49] raise hope that similar successes may be achieved with MCE-SDS.

During the SAX-HPLC run, the employed salt gradient for the elution introduces a large amount of nonvolatile ions, effectively eliminating the possibility of using MS. However, the individual fractions contain only a fractional amount of the initial total protein amount, reducing the complexity of the sample. By means of buffer exchange to a volatile, MS compatible buffer, the individual fractions could be analyzed with MS. Direct coupling of cation [50] and anion exchange chromatography [12] with MS has been reported. The employed strategies could also be applied for further developments of the first dimension if MS compatibility is desired.

\section{Samples from $\mathrm{CHO}$ cell culture containing an IgG antibody}

The resulting separations are shown in Fig. 3. The peak at $7 \mathrm{kDa}$ is the aforementioned system peak. Most protein is contained in fractions 2,3 , and $10-15$. The peak around $175 \mathrm{kDa}$ accounts for most of the protein. In this example, peaks were assigned based on their apparent molecular mass. All peaks with approximately $175 \mathrm{kDa}$ were assigned as IgG, while the rest of the peaks was regarded as impurities. Non-reduced conditions were chosen, due to a possible overlap of the peaks from the IgG light chain and impurities around $30 \mathrm{kDa}$ under reduced conditions. The majority of the impurities can be found in the same fractions as the $\operatorname{IgG}$ $(2,3,10-15)$, effectively overlapping with the elution of the IgG antibody during the SAX-HPLC run. The effect of the protein A purification can be seen in Fig. 3b. The total percentage area of non-IgG peaks is reduced, from about 17 to $8 \%$. The effect is also visible in the exemplary electropherograms in Fig. 3c. The total protein concentration of the supernatant and purified antibody solution was $4.5 \mathrm{mg} / \mathrm{mL}$ and $3.1 \mathrm{mg} / \mathrm{mL}$, respectively. Due to that, the results should be seen with caution. The isoelectric point (pI) of many IgG $\mathrm{mAbs}$ is found in basic regions [54]. Improved retention and
Fig. 2 Cutouts of the immunoblots of the $21^{\text {st }}$ fraction of each separation depicted in Fig. 1 ("after separation") and of the corresponding raw Sf9 cytosol lysates ("raw material"), with primary antibody for $\alpha_{1}$ subunit (a) and with primary antibody for $\beta_{1}$ subunit (b); position of the ladder proteins and their nominal molecular mass are indicated on the left side of the images

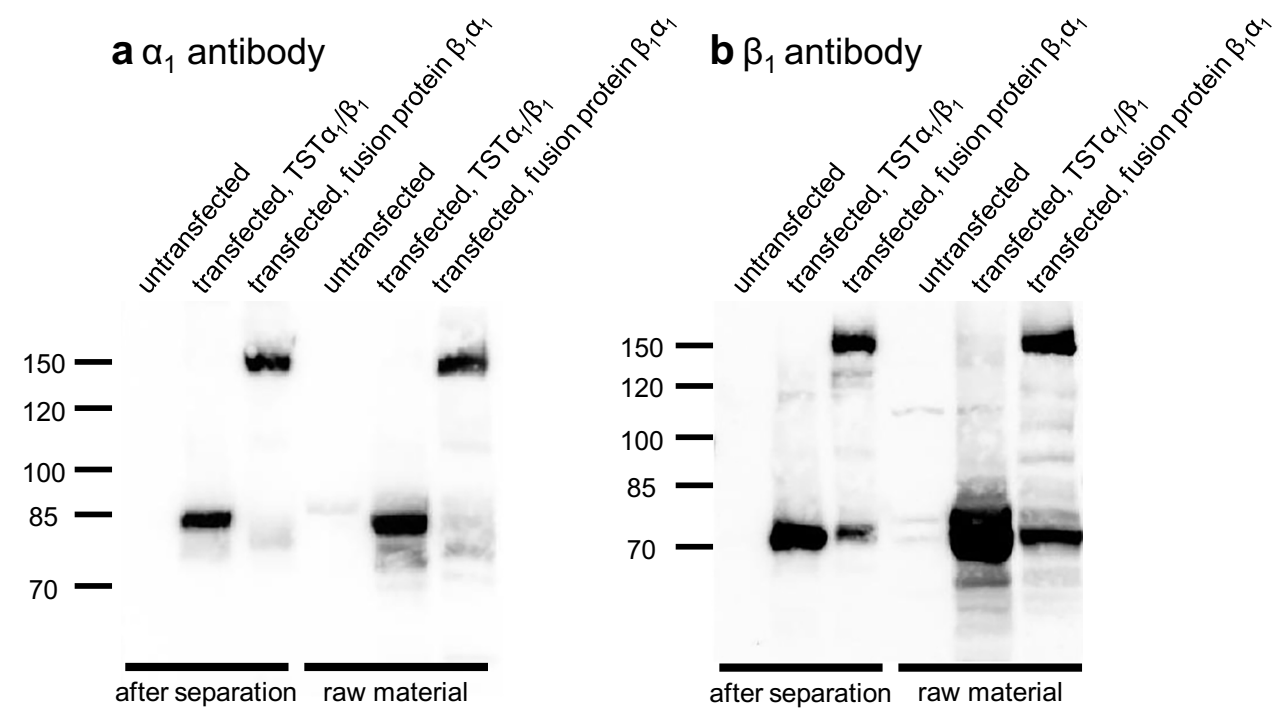




\section{a Supernatant}

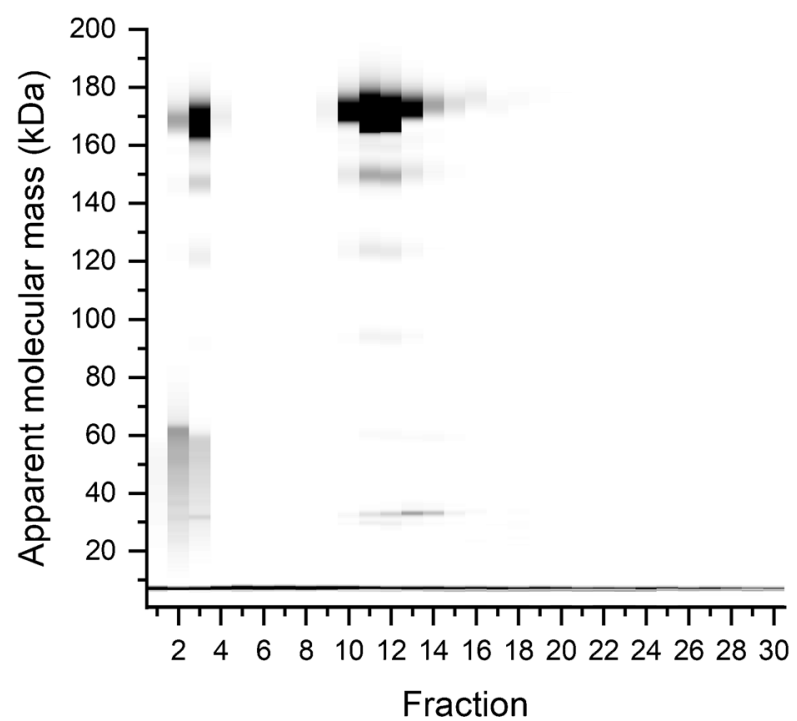

b Purified antibody

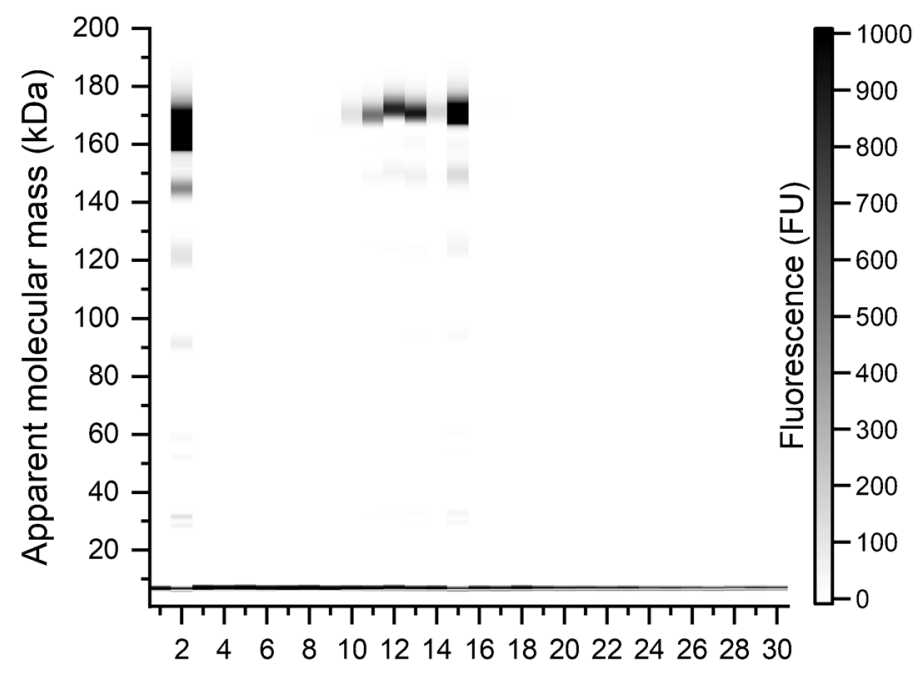

Fraction

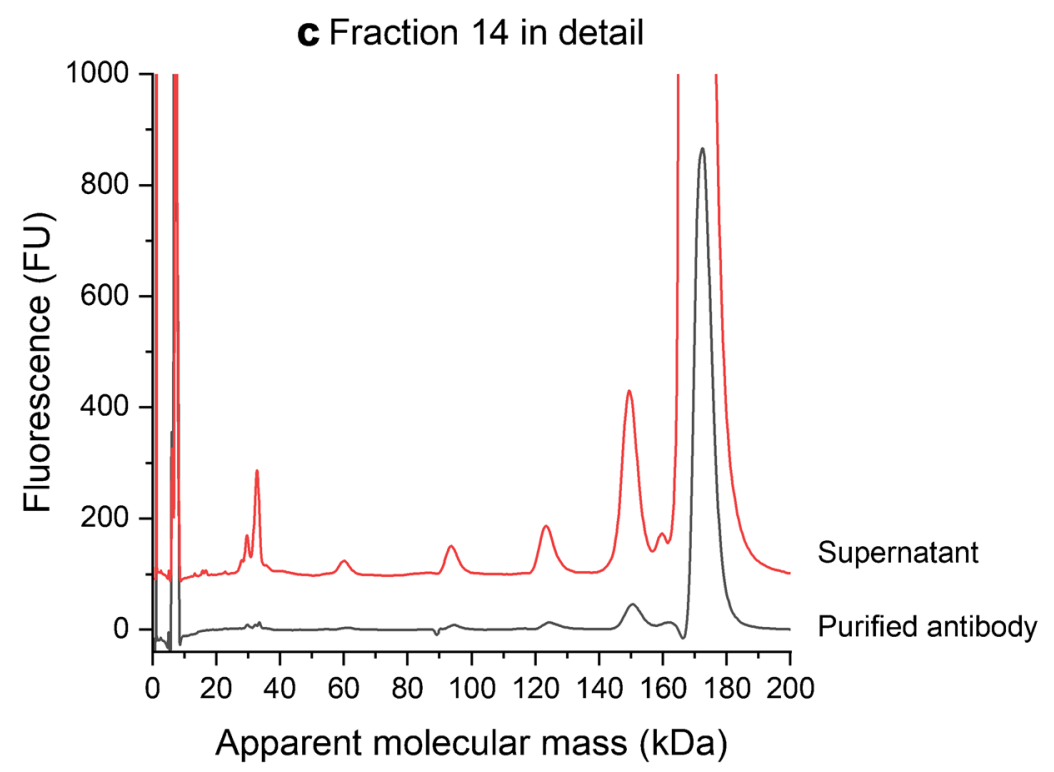

Fig. 3 Two-dimensional separations (non-reduced conditions) of $\mathrm{CHO}$ cell culture supernatant before (a) and after protein A purification (purified antibody, b); injection volume $3000 \mu \mathrm{L}$ for both; in c, two exemplary electropherograms of the $14^{\text {th }}$ fraction of each separa-

separation might be obtained using strong cation exchange instead of SAX and could be an alternative for similar samples in the future.

\section{Fresh-frozen human plasma}

An exemplary separation of $500 \mu \mathrm{L}$ human plasma is depicted in Fig. 4a. The protein concentration of the injected solution was $30.5 \mathrm{mg} / \mathrm{mL}$. Most peaks were found in the $2^{\text {nd }}$ and $10^{\text {th }}$ to $19^{\text {th }}$ fraction. Only few peaks above $120 \mathrm{kDa}$ are visible. tion are depicted, the upper red trace from the supernatant and the lower, black trace from the purified mAb. The intensity of the impurity peaks $(10-165 \mathrm{kDa})$ is greatly reduced in the black trace

The human plasma proteome is well known $[30,31$, 55] and classical 2-DE employs a comparable separation mechanism. A detailed depiction of a 2-DE separation of human plasma is provided in [56]. Further 2-DE separations may be found in several other publications [57, 58]. Generally, the elution order in our approach is the opposite as in 2-DE, from basic to acidic proteins. The proposed assignment of the peaks is based on their relative abundance, their apparent molecular mass, and their relative positions to each other. The most abundant protein is albumin [31] (calculated molecular mass based on amino acid sequence 

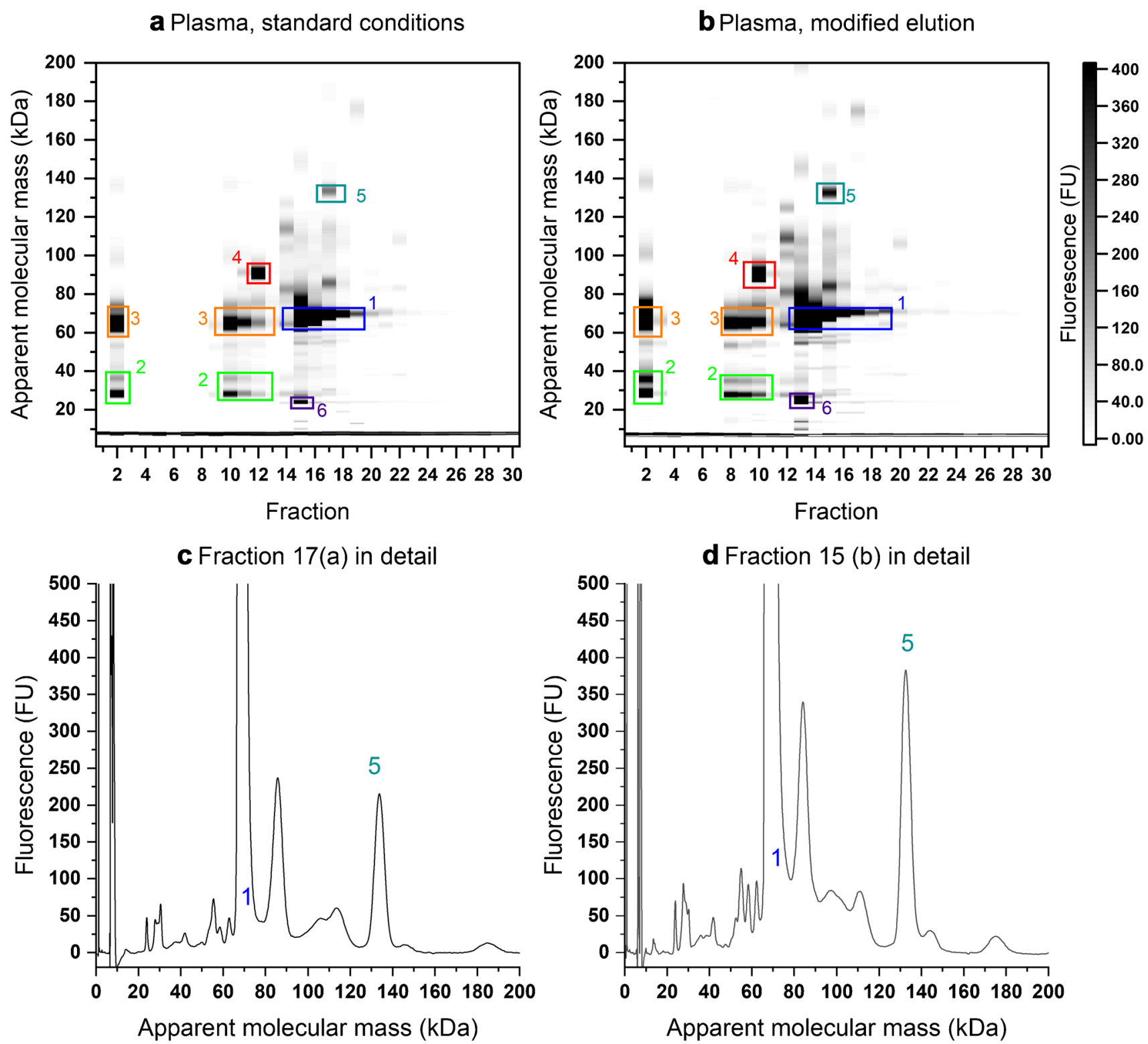

Fig. 4 Two-dimensional separations (reduced conditions) of $500 \mu \mathrm{L}$ human plasma under standard conditions (a) and with modified elution: flow rate $1 \mathrm{~mL} / \mathrm{min}$, linear gradient from 0 to $100 \%$ MPB over $40 \mathrm{~min}$ (b), the peaks are presumed to be albumin (1), Ig light chains

(cMM) $66 \mathrm{kDa}$ [30]), which corresponds to peaks "1" (blue box) around $64 \mathrm{kDa}$ in fractions 15 to 19 . In fraction 2 and in 10 to 12 , the peaks " 2 " (green box) around 24 and $27 \mathrm{kDa}$ presumably are immunoglobulin light chains (cMM $23 \mathrm{kDa}[30]$ ) and peaks "3" (orange box) around $65 \mathrm{kDa}$ (cMM 53-75 kDa [30]) the corresponding heavy chains. The peak "4" (red box) at $90 \mathrm{kDa}$ in fraction 12 could be serotransferrin (cMM $75 \mathrm{kDa}$ [30]). Both, immunoglobulins and serotransferrin, can be found at more basic pIs than albumin in 2-DE [56]. Furthermore, the peak " 5 " (petrol box) at $134 \mathrm{kDa}$ in fraction 17 could be ceruloplasmin (cMM
(2), Ig heavy chains (3), serotransferrin (4), ceruloplasmin (5), and apolipoprotein A1 (6); detailed view of two electropherograms from fraction 17 of the separation in $4 \mathrm{a}(\mathbf{c})$ and from fraction 15 of the separation in $4 \mathrm{~b}(\mathbf{d})$, peaks 1 and 5 are indicated in both traces

$120 \mathrm{kDa}[30]$ ) and the peak " 6 " (purple box) in fraction 15 around $24 \mathrm{kDa}$ might be apolipoprotein A1 (cMM $28 \mathrm{kDa}$ [30]). Overall, the pattern seems similar to those of the aforementioned 2-DE separations, if the assignment is correct. For a definitive statement, confirmation of peak identity would be necessary.

Several changes of the method were conducted and tested. The short isocratic hold time ( $5 \mathrm{~min}$ ) at the beginning of the method was removed. The dwell volume of the used HPLC system is large $(7.6 \mathrm{~mL})$. Therefore, the gradient needs about $5.85 \mathrm{~min}$ at $1.3 \mathrm{~mL} / \mathrm{min}$ (or $7.6 \mathrm{~min}$ at $1 \mathrm{~mL} / \mathrm{min}$ ) until it 
reaches the column inlet. This should be a sufficient isocratic hold time for a gradient method. As a result, the same separation in a shorter timeframe (40 $\mathrm{min})$ was obtained. The number of fractions remained constant, effectively reducing the individual fraction's volume and increasing the sensitivity. Second, the flow rate was reduced to $1 \mathrm{~mL} / \mathrm{min}$. This yielded a higher sensitivity without impairing the separation. The combined effect of both changes can be seen in Fig. $4 \mathrm{~b}$. In comparison to Fig. 4a, the separation remains unaffected but is shifted leftwards, two fractions earlier. Additionally, the intensity of the peaks increases. This is very well visible, but, due to the chosen gray-scale, only for the low abundant peaks. For example, the intensity of the peak " 5 " around $133 \mathrm{kDa}$ in fraction 17 (standard conditions, Fig. 4c), respective 15 (modified conditions, Fig. 4d), increased from 215 to $382 \mathrm{FU}$. Nevertheless, it applies also to the high abundant peaks, e.g., the peak "1" around $67 \mathrm{kDa}$ in fraction 17 (standard conditions) has an intensity of $\approx 3000 \mathrm{FU}$, while in fraction 15 (modified conditions) the intensity is at about $5700 \mathrm{FU}$. The effect is also visible in the chromatograms. The peak intensity is increased and the peaks are shifted to earlier retention times while preserving the original peak pattern (SI Fig. 4).

The $\mathrm{pH}$ value of the sample might influence the retention and therefore the separation. The sample's $\mathrm{pH}$ was increased from 8.24 to 9.59 and 10.55. Higher $\mathrm{pH}$ led to an unchanged separation, with some decrease in peak intensity (data not shown). This might be due to precipitation. Overall, the separation is robust to a basic shift in the sample's $\mathrm{pH}$ value.

Due to the limited protein capacity of the column, the high abundance of albumin creates a challenge for the detection of proteins with much lower concentrations. The proven and tested strategies used in 2-DE for the depletion of the most abundant proteins $[59,60]$ could also be applied here and should allow for more individual proteins to be detected.

\section{Performance}

\section{Repeatability}

Three consecutive injections of $750 \mu \mathrm{L}$ Sf9 cytosol lysate $(53.4 \mathrm{mg} / \mathrm{mL}$ before dilution) were analyzed. The following method parameters differed from the described parameters: $1+1$ dilution with lysis buffer, 25 fractions over $37.5 \mathrm{~min}$ were collected. A peak with a comparatively low intensity (signal to noise ratio $(\mathrm{S} / \mathrm{N}) \approx 5$ ) and a peak with a normal intensity $(\mathrm{S} / \mathrm{N}>100)$ were investigated. The low intensity peak can be seen as a "worst-case scenario," while the normal intensity peak represents a normal use case. The S/N was calculated according to the European Pharmacopoeia [61]. The electropherograms were integrated and all peaks within the assay's specified range (10-200 kDa) included. Time corrected areas (corr. area) were obtained from the
LabChip's software and used for further calculation. The relative standard deviation (RSD) of the corr. area and of the percentage of the corr. area of the individual peak to the total corr. area of all peaks in the fraction (\%area) was calculated. The RSDs for the low intensity peak were $15.5 \%$ (corr. area) and $21.9 \%$ (\%area), while for the normal intensity peak they were $20.6 \%$ (corr. area) and $10.1 \%$ (\%area). These values are in the order of magnitude of previously reported values for this particular LabChip ${ }^{\circledR}$ assay [62] and within the specifications given by the manufacturer (up to $30 \%$ RSD for quantitation) [18]. Improved values might be obtained by averaging the values from multiple MCE-SDS injections of the same sample at the expense of speed [62]. For this sample, injecting every fraction twice improved the RSD for the normal intensity peak to $17.7 \%$ (corr. area) and 9.73\% (\%area). The RSDs for the low intensity peak did not benefit from this, with values of $23.2 \%$ (corr. area) and $21.7 \%$ (\%area). In this case, the low $\mathrm{S} / \mathrm{N}$ has a major influence on precision, since the $\mathrm{S} / \mathrm{N}$ needs to be $>100$ for optimal precision [63]. Further improvements may be achieved with the ProteinEXact assay, which has tighter specification limits for quantification $[64,65]$.

\section{Expected sensitivity}

The MCE-SDS assay's linear concentration range starts at $5 \mathrm{ng} / \mu \mathrm{L}$ [18], and Kahle et al. [62] reported an $\mathrm{S} / \mathrm{N}$ of 44 at $10 \mathrm{ng} / \mu \mathrm{L}$ for carbonic anhydrase. One fraction contains about $1950 \mu \mathrm{L}$ eluate, division through the aforementioned $5 \mathrm{ng} / \mu \mathrm{L}$ leads to at least $9.75 \mu \mathrm{g}$ of protein required per fraction. Assuming a recovery of $85 \%$, at least $11.5 \mu \mathrm{g}$ need to be injected $\left(\frac{9.75 \mu g}{85 \%}=11.5 \mu \mathrm{g}\right)$. The typical injection volume ranges from 100 to $3000 \mu \mathrm{L}$. Assuming $1000 \mu \mathrm{L}$ are injected, the protein's concentration should be $11.5 \mathrm{ng} / \mu \mathrm{L}$ or higher to be detectable.

Porebski et al. [66] report an influence of the salt concentration on peak areas during CE-SDS. Since the LabChip ${ }^{\circledR}$ moves the sample electrokinetically into the separation channel [35], an influence on the areas can also be reasonably expected here. This was confirmed by adding equal amounts of BSA to each fraction of a blind run. The peak area is negatively correlated with the salt concentration (SI Fig. 5). This should be continued to be investigated in conjunction with further method changes. The previously described method changes represent a good starting point. Another possibility is the use of the Protein Pico Assay. Here, a sensitivity of approximately $10-50 \mathrm{pg} / \mu \mathrm{L}$, which corresponds to a 100-fold improvement over the Protein Express Assay, can be expected [67]. The drawback is that a buffer exchange would be necessary. Other two-dimensional HPLC $\times$ CE approaches use evaporation and reconstitution [68]. In our case, this would unfavorably increase the salt concentration. 


\section{Peak capacity}

An easy and convenient way for the assessment of the peak capacity is simply counting peaks. Each MCE-SDS run's electropherogram was integrated and all peaks with an apparent molecular mass $\geq 10 \mathrm{kDa}$ were counted. The results from all 30 electropherograms were summed. For the most complex sample, namely Sf9 cytosol lysate, between 330 (sample Fig. 1a) and 419 peaks (sample Fig. 1b) were achieved. Human plasma (sample Fig. 4b) counted 218 peaks. One possibility to increase the peak capacity could be an increased amount of fractions. For HPLC $\times$ HPLC separations, the requirement was stated that ideally each peak in the first dimension should be sampled at least three to four times [69]. This concept has been refined in subsequent publications [70, 71], and moreover, it has been frequently cited. However, to be precise, this concept and derived concepts are only applicable for HPLC $\times$ HPLC separations. Since the theories about peak capacity, sampling frequency, etc. are not as well developed for CE based separations [72], it can only be assumed that a similar impact can be achieved here. Further refinements of the first dimension may provide an additional option to increase the peak capacity.

\section{Speed}

The presented approach uses commercially available instruments, which can be set up and operated in any lab. This facilitates an easy implementation. The approach is fast and might be accelerated even more. The expected run time for one sample is approximately $3 \mathrm{~h}$. The time is based on the following assumptions: 45 min HPLC preparation, 15 min sample preparation, 45 min HPLC separation, 10 min fraction handling, $30 \mathrm{~min}$ fraction preparation for MCE-SDS, 5 min chip preparation and cleaning, 30 min MCE-SDS runs. An online approach is not easily feasible due to the required heating during sample preparation for the $2^{\text {nd }}$ dimension. Several other possibilities arise to streamline the process. Running consecutive analyses and the second dimension in parallel with the first dimension of the next samples reduces analysis time to approximately $1.5 \mathrm{~h}$ per sample with the present setup. The initial publication describing the stationary phase points out the possibility of using high linear velocities [16]. In a preliminary experiment using human plasma, the flow rate was doubled from 1 to $2 \mathrm{~mL} / \mathrm{min}$. Consequently, the HPLC run was completed within $35 \mathrm{~min}$. The resulting chromatogram and two-dimensional separation are shown in SI Fig. 6. This is another promising possibility to increase the separation speed and will be the scope of further investigations.

Currently, the fractions are collected in 2-mL microcentrifuge tubes. With the appropriate, commercially available equipment, fraction collection directly in 96 -well plates is possible. The required reduced flow rate could be either obtained using a flow splitter or by miniaturization of the separation process. The collection into a 96 -well plate would speed up the preparation process for the MCE-SDS analysis considerably. Another possibility is the automation of the remaining manual steps. Particularly pipetting could be sped up by automation and reduce hands-on time. If one is routinely analyzing the same sample and is only interested in particular proteins, an adaption of the gradient and reduction of the fraction amount could further increase the speed. This implies a switch from a comprehensive to a heart-cutting approach.

\section{Size and pl range}

The size-based assay is suited for apparent molecular masses between 10 and $200 \mathrm{kDa}$. Below $10 \mathrm{kDa}$, system peaks interfere with potential sample peaks. In the different samples, proteins over the whole range were found. The Protein Low Molecular Weight Assay could offer an alternative for proteins within the 5-80 kDa range, but a buffer exchange is required for fractions containing more than $0.5 \mathrm{M} \mathrm{NaCl}$ [73].

Generally speaking, proteins need to possess a negative charge to be retained on the column. As a rule of thumb, this necessitates a pI below 7.5-6.5 [9], the lower the better the retention. Several individual proteins were analyzed by SAX chromatography at a concentration of $1 \mathrm{mg} / \mathrm{mL}$ in MPA. The resulting chromatograms are presented in SI Fig. 7. Matuzumab is a mAb with a pI of 8.3 (main species)-7.5 (SI Fig. 8). The peak's maximum is at $14.7 \mathrm{~min}$, which is shortly after the beginning of the salt gradient. The other proteins possess a lower pI, Ovalbumin 4.7-4.9 [74, 75], BSA 4.6-5 [76-78], HSA 4.7-5.7 [79-81], and $\beta$-Lactoglobulin 5.2 [82, 83]. Their retention times were $21.3 \mathrm{~min}$ (Ovalbumin), $24.3 \mathrm{~min}$ (BSA), $24.8 \mathrm{~min}$ (HSA), and $26.1 \mathrm{~min}$ ( $\beta$-Lactoglobulin). The proteins identified in the human plasma sample are found between $\mathrm{pI} 4$ and 8 in 2-DE [58]. Based on these results, the estimated covered pI range is from about 4 to 8 . However, non-retained proteins are not lost, but simply found in the first fractions.

These considerations should also take into account that the net charge alone is not always sufficient for the explanation of the retention. The (unequal) surface charge distribution, the displacing salt, stationary phase, and protein-protein interactions may influence the retention and sometimes complicate general assumptions $[84,85]$.

The aforementioned use of a cation exchange column instead of an anion exchange column could expand the covered range through the altered selectivity. This might be relevant if the attention is on basic proteins and will be subject of further investigations. 


\section{Conclusion}

The presented approach was very well applicable to the three different examples, clearly demonstrating its feasibility. The IgG containing cell culture supernatant as well as the Sf9 cytosol lysate demonstrated the use of the approach for biotechnological process control or analysis. The latter one focused on a specific protein in a complex matrix and the former focused on the changes during a process. The protein sGC could be confidently identified. The results from the human plasma separation and their comparison to conventional 2-DE results revealed that the underlying comparable separation mechanism might lead to similar but not directly transferable results.

In all cases, quick two-dimensional separations were achieved. The potential for further acceleration of the separation process was highlighted. Method improvements, especially in the first dimension, should further improve this approach. Potential steps were outlined and briefly discussed. Using best-suited separation systems in the first dimension can also customize this approach for individual requirements and sample properties. The second dimension offers fewer opportunities for refinement.

With refined parameters, the determination of additional relevant method parameters, e.g., reproducibility, linearity, robustness, etc., is of interest. Further research with the objective of expanding the applications to e.g. impurity analysis, diagnostics, or process analytics will help to gain a more thorough understanding of the technique's properties.

Supplementary Information The online version contains supplementary material available at https://doi.org/10.1007/s00216-021-03797-4.

Acknowledgements Special thanks to PerkinElmer, in particular to Dr. James Atwood, for providing the LabChip ${ }^{\circledR}$ GX II Touch ${ }^{\mathrm{TM}}$ instrument and supplying the reagents required for it. The $\mathrm{CHO}$ cell culture samples were kindly provided by UGA Biopharma $\mathrm{GmbH}$. The fresh-frozen human plasma was generously provided by the Institut für Transfusionsmedizin, Städtisches Klinikum Braunschweig gGmbH. The technical assistance of Ines Glöckner is gratefully acknowledged. Furthermore, we thank Christin Scheller and Finja Krebs for carefully reading and improving our manuscript and Dr. Imke Oltmann-Norden, Dr. Robert Minkner, and Ratih for their support.

Author contribution Conceptualization: Holger Zagst, Hermann Wätzig. Methodology: Holger Zagst, Hermann Wätzig. Formal analysis and investigation: Holger Zagst, Christin Elgert. Writing—original draft preparation: Holger Zagst. Writing—review and editing: Holger Zagst, Christin Elgert, Sönke Behrends, Hermann Wätzig. Funding acquisition: Hermann Wätzig. Resources: Hermann Wätzig, Sönke Behrends. Supervision: Hermann Wätzig, Sönke Behrends.

Funding Open Access funding enabled and organized by Projekt DEAL.

Data availability The datasets generated during and/or analyzed during the current study are available from the corresponding author on reasonable request.
Code availability Not applicable.

\section{Declarations}

Competing interests Hermann Wätzig is co-inventor and the TU Braunschweig applicant of the patent WO 2018/127515 A1, which provides the framework for this manuscript. All other authors declare that they do not have any conflict of interest.

Open Access This article is licensed under a Creative Commons Attribution 4.0 International License, which permits use, sharing, adaptation, distribution and reproduction in any medium or format, as long as you give appropriate credit to the original author(s) and the source, provide a link to the Creative Commons licence, and indicate if changes were made. The images or other third party material in this article are included in the article's Creative Commons licence, unless indicated otherwise in a credit line to the material. If material is not included in the article's Creative Commons licence and your intended use is not permitted by statutory regulation or exceeds the permitted use, you will need to obtain permission directly from the copyright holder. To view a copy of this licence, visit http://creativecommons.org/licenses/by/4.0/.

\section{References}

1. Stoll DR, Carr PW. Two-dimensional liquid chromatography: a state of the art tutorial. Anal Chem. 2017. https://doi.org/10.1021/ acs.analchem.6b03506.

2. Rabilloud T, Chevallet M, Luche S, Lelong C. Two-dimensional gel electrophoresis in proteomics: past, present and future. J Proteomics. 2010. https://doi.org/10.1016/j.jprot.2010.05.016.

3. Ranjbar L, Foley JP, Breadmore MC. Multidimensional liquidphase separations combining both chromatography and electrophoresis - a review. Anal Chim Acta. 2017. https://doi.org/10. 1016/j.aca.2016.10.025.

4. Kohl FJ, Sánchez-Hernández L, Neusüß C. Capillary electrophoresis in two-dimensional separation systems: techniques and applications. Electrophoresis. 2015. https://doi.org/10.1002/elps. 201400368.

5. Stroink T, Ortiz MC, Bult A, Lingeman H, de Jong GJ, Underberg WJM. On-line multidimensional liquid chromatography and capillary electrophoresis systems for peptides and proteins. J Chromatogr B. 2005. https://doi.org/10.1016/j.jchromb.2004.11.057.

6. Evans CR, Jorgenson JW. Multidimensional LC-LC and LC-CE for high-resolution separations of biological molecules. Anal Bioanal Chem. 2004. https://doi.org/10.1007/s00216-004-2516-2.

7. Goyon A, Dai L, Chen T, Wei B, Yang F, Andersen N, Kopf R, Leiss M, Mølhøj M, Guillarme D, Stella C. From proof of concept to the routine use of an automated and robust multi-dimensional liquid chromatography mass spectrometry workflow applied for the charge variant characterization of therapeutic antibodies. J Chromatogr A. 2020. https://doi.org/10.1016/j.chroma.2019. 460740.

8. Hille JM, Freed AL, Wätzig H. Possibilities to improve automation, speed and precision of proteome analysis: a comparison of two-dimensional electrophoresis and alternatives. Electrophoresis. 2001. https://doi.org/10.1002/1522-2683(200111)22:19\%3c4035: AID-ELPS4035\%3e3.0.CO;2-9.

9. Fekete S, Beck A, Veuthey J-L, Guillarme D. Ion-exchange chromatography for the characterization of biopharmaceuticals. J Pharm Biomed Anal. 2015. https://doi.org/10.1016/j.jpba.2015. 02.037 . 
10. Sänger-van de Griend CE. CE-SDS method development, validation, and best practice-An overview. Electrophoresis. 2019. https:// doi.org/10.1002/elps.201900094.

11. Zhu Z, Lu JJ, Liu S. Protein separation by capillary gel electrophoresis: a review. Anal Chim Acta. 2012. https://doi.org/10.1016/j. aca.2011.10.022.

12. van Schaick G, Gstöttner C, Büttner A, Reusch D, Wuhrer M, Domínguez-Vega E. Anion exchange chromatography - mass spectrometry for monitoring multiple quality attributes of erythropoietin biopharmaceuticals. Anal Chim Acta. 2021. https://doi. org/10.1016/j.aca.2020.11.027.

13. He Y, Pang HM, Lou S, Han F. Two-dimensional protein separations using chromatofocusing and multiplexed capillary gel electrophoresis. US20030377909;G01N27/447;G01N27/447 (WO2004079357 (A1)); 2004.

14. Maul-Köhler KJ. In preparation. Doctoral thesis, Technische Universität Braunschweig; 2022.

15. Wätzig H, Maul KJ, Kahle J, Hahne T. Method for Two-dimensional Protein Separation and Protein-Separating Device: International Patent (WO 2018/127515 A1 EPN 3566045); 2018.

16. Lloyd LL, Warner FP. Preparative high-performance liquid chromatography on a unique high-speed macroporous resin. J Chromatogr A. 1990. https://doi.org/10.1016/S0021-9673(01)89502-9.

17. Agilent Technologies Inc. COLUMN USER GUIDE for Agilent BioHPLC and AdvanceBio Columns; 2014.

18. PerkinElmer, Inc. Protein Express User Guide: For LabChip GXII Touch and LabChip GXII. PerkinElmer, Inc. 2014-2015. https:// www.perkinelmer.com/lab-solutions/resources/docs/GDE_Pico_ Protein_Express_User_Guide.pdf. Accessed 13 Jan 2021.

19. Granados RR, Li G, Blissard GW. Insect cell culture and biotechnology. Virol Sin. 2007. https://doi.org/10.1007/ s12250-007-0010-7.

20. Ignarro LJ, Buga GM, Wood KS, Byrns RE, Chaudhuri G. Endothelium-derived relaxing factor produced and released from artery and vein is nitric oxide. Proc Natl Acad Sci U S A. 1987. https://doi.org/10.1073/pnas.84.24.9265.

21. Lill JR, Sandoval W. Analytical characterization of biotherapeutics. Somerset: John Wiley \& Sons Incorporated; 2017.

22. United States Pharmacopeial Convention. United States Pharmacopeia and National Formulary (USP 39-NF 34): <1132> Residual Host Cell Protein Measurement in Biopharmaceuticals. Rockville, MD: United States Pharmacopeial Convention; 2016.

23. Prakash K, Chen W. Analytical methods for the measurement of host cell proteins and other process-related impurities. In: Schiel JE, Davis DL, Borisov OV, editors. State-of-the-Art and Emerging Technologies for Therapeutic Monoclonal Antibody Characterization Volume 2. Biopharmaceutical Characterization: The NISTmAb Case Study, vol. 1201. Washington, DC: American Chemical Society; 2015. pp. 387-404.

24. EDQM Council of Europe. European Pharmacopoeia: 2.6.34. Bestimmung von Wirtszellproteinen. $10^{\text {th }}$ ed. Stuttgart: Deutscher Apotheker Verlag; 2020.

25. Tscheliessnig AL, Konrath J, Bates R, Jungbauer A. Host cell protein analysis in therapeutic protein bioprocessing - methods and applications. Biotechnol J. 2013. https://doi.org/10.1002/biot. 201200018.

26. Obrstar D, Kröner F, Japelj B, Bojic L, Anderka O. Host cell protein profiling in biopharmaceutical harvests. Anal Chem. 2018. https://doi.org/10.1021/acs.analchem.8b01236.

27. World Health Organization. Recommendations for the production, control and regulation of human plasma for fractionation - Annex 4. WHO Technical Report Series; 2007.

28. European Medicines Agency. Guideline on plasma-derived medicinal products. London: United Kingdom; 2011.
29. Jelkmann W. Blut. In: Schmidt RF, Lang F, editors. Physiologie des Menschen. Berlin, Heidelberg: Springer Berlin Heidelberg; 2007. pp. 523-549.

30. Schaller J. Human blood plasma proteins: structure and function. Chichester: Wiley; 2008.

31. Anderson NL, Anderson NG. The human plasma proteome: history, character, and diagnostic prospects. Mol Cell Proteomics. 2002. https://doi.org/10.1074/mcp.r200007-mcp200.

32. Schwenk JM, Omenn GS, Sun Z, Campbell DS, Baker MS, Overall CM, Aebersold R, Moritz RL, The DEW, Draft HPP, of,. building on the human plasma PeptideAtlas from mass spectrometry and complementary assays. J Proteome Res. 2017;2017. https:// doi.org/10.1021/acs.jproteome.7b00467.

33. Issaq HJ, Xiao Z, Veenstra TD. Serum and plasma proteomics. Chem Rev. 2007. https://doi.org/10.1021/cr068287r.

34. Chow AW. DNA Separations. In: Henry CS, editor. Microchip capillary electrophoresis. Methods and protocols. Totowa, NJ: Humana Press; 2006. pp. 129-144.

35. Chen X, Tang K, Lee M, Flynn GC. Microchip assays for screening monoclonal antibody product quality. Electrophoresis. 2008. https://doi.org/10.1002/elps.200800324.

36. Chow AW. Protein separations. In: Henry CS, editor. Microchip capillary electrophoresis. Methods and protocols, vol. 339. Totowa, NJ: Humana Press; 2006. pp. 145-158.

37. Chow AW, Fathollahi B, Mikkelsen, James C., Jr., Spaid MA, Winoto A. Methods, Devices and System for Characterizing Proteins: International Patent;G01N 27/26(WO 2005/075967 A1); 2005.

38. LabChip GXII Touch Protein Characterization System Product Note. PerkinElmer, Inc. 2019. https://perkinelmer-appliedgen omics.com/wp-content/uploads/2019/08/LabChip-GXII-TouchProduct-Note-AG011908_06_PN.pdf. Accessed 19 Aug 2021.

39. Bousse L, Mouradian S, Minalla A, Yee H, Williams K, Dubrow R. Protein sizing on a microchip. Anal Chem. 2001. https://doi. org/10.1021/ac0012492.

40. Bradford MM. A rapid and sensitive method for the quantitation of microgram quantities of protein utilizing the principle of protein-dye binding. Anal Biochem. 1976. https://doi.org/10.1016/ 0003-2697(76)90527-3.

41. Life Technologies. Bac-to-Bac baculovirus expression system: an efficient site-specific transposition system to generate baculovirus for high-level expression of recombinant proteins. Life Technologies. 2015. http://tools.thermofisher.com/content/sfs/manuals/ bactobac_man.pdf. Accessed 14 Apr 2021.

42. Elgert C, Rühle A, Sandner P, Behrends S. A novel soluble guanylyl cyclase activator, BR 11257, acts as a non-stabilising partial agonist of sGC. Biochem Pharmacol. 2019. https://doi.org/10. 1016/j.bcp.2019.02.007.

43. Koglin M, Vehse K, Budaeus L, Scholz H, Behrends S. Nitric oxide activates the beta 2 subunit of soluble guanylyl cyclase in the absence of a second subunit. J Biol Chem. 2001. https://doi. org/10.1074/jbc.M102549200.

44. Koglin M, Behrends S. Cloning and functional expression of the rat alpha(2) subunit of soluble guanylyl cyclase. Biochim Biophys Acta. 2000. https://doi.org/10.1016/s0167-4781(00)00211-6.

45. Haase T, Haase N, Kraehling JR, Behrends S. Fluorescent fusion proteins of soluble guanylyl cyclase indicate proximity of the heme nitric oxide domain and catalytic domain. PLoS ONE. 2010. https://doi.org/10.1371/journal.pone.0011617.

46. Haase N, Haase T, Kraehling JR, Behrends S. Direct fusion of subunits of heterodimeric nitric oxide sensitive guanylyl cyclase leads to functional enzymes with preserved biochemical properties: evidence for isoform specific activation by ciguates. Biochem Pharmacol. 2010. https://doi.org/10.1016/j.bcp.2010.08.007. 
47. Kamisaki Y, Saheki S, Nakane M, Palmieri JA, Kuno T, Chang BY, Waldman SA, Murad F. Soluble guanylate cyclase from rat lung exists as a heterodimer. J Biol Chem. 1986;261:7236-41.

48. Janini GM, Chan KC, Conrads TP, Issaq HJ, Veenstra TD. Twodimensional liquid chromatography-capillary zone electrophoresis-sheathless electrospray ionization-mass spectrometry: evaluation for peptide analysis and protein identification. Electrophoresis. 2004. https://doi.org/10.1002/elps.200405948.

49. Mack S, Arnold D, Bogdan G, Bousse L, Danan L, Dolnik V, Ducusin M, Gwerder E, Herring C, Jensen M, Ji J, Lacy S, Richter C, Walton I, Gentalen E. A novel microchip-based imaged CIEFMS system for comprehensive characterization and identification of biopharmaceutical charge variants. Electrophoresis. 2019. https://doi.org/10.1002/elps.201900325.

50. Füssl F, Cook K, Scheffler K, Farrell A, Mittermayr S, Bones J. Charge variant analysis of monoclonal antibodies using direct coupled $\mathrm{pH}$ gradient cation exchange chromatography to highresolution native mass spectrometry. Anal Chem. 2018. https:// doi.org/10.1021/acs.analchem.7b05241.

51. Römer J, Kiessig S, Moritz B, Neusüß C. Improved CE(SDS)CZE-MS method utilizing an 8-port nanoliter valve. Electrophoresis. 2021. https://doi.org/10.1002/elps.202000180.

52. Lu JJ, Zhu Z, Wang W, Liu S. Coupling sodium dodecyl sulfate-capillary polyacrylamide gel electrophoresis with matrixassisted laser desorption ionization time-of-flight mass spectrometry via a poly(tetrafluoroethylene) membrane. Anal Chem. 2011. https://doi.org/10.1021/ac103148k.

53. Sánchez-Hernández L, Montealegre C, Kiessig S, Moritz B, Neusüß C. In-capillary approach to eliminate SDS interferences in antibody analysis by capillary electrophoresis coupled to mass spectrometry. Electrophoresis. 2017. https://doi.org/10. 1002/elps.201600464.

54. Goyon A, Excoffier M, Janin-Bussat M-C, Bobaly B, Fekete S, Guillarme D, Beck A. Determination of isoelectric points and relative charge variants of 23 therapeutic monoclonal antibodies. J Chromatogr B Analyt Technol Biomed Life Sci. 2017. https://doi.org/10.1016/j.jchromb.2017.09.033.

55. Anderson NL, Polanski M, Pieper R, Gatlin T, Tirumalai RS, Conrads TP, Veenstra TD, Adkins JN, Pounds JG, Fagan R, Lobley A. The human plasma proteome: a nonredundant list developed by combination of four separate sources. Mol Cell Proteomics. 2004. https://doi.org/10.1074/mcp.M3001 27-MCP200.

56. Anderson L, Anderson NG. High resolution two-dimensional electrophoresis of human plasma proteins. Proc Natl Acad Sci U S A. 1977. https://doi.org/10.1073/pnas.74.12.5421.

57. Manabe T, Kojima K, Jitzukawa S, Hoshino T, Okuyama T. Normalization of two-dimensional electrophoretic patterns of human plasma proteins and comparisons of cerebrospinal fluid and urine patterns in terms of the normalized map. J Biochem. 1981. https://doi.org/10.1093/oxfordjournals.jbchem.a133267.

58. Mukai J, Yamaguchi N, Manabe T. Two-dimensional separation of human plasma proteins using agarose gel isoelectric focusing followed by SDS capillary electrophoresis. Chromatography. 2003;24:127-33.

59. Greenough C, Jenkins RE, Kitteringham NR, Pirmohamed M, Park BK, Pennington SR. A method for the rapid depletion of albumin and immunoglobulin from human plasma. Proteomics. 2004. https://doi.org/10.1002/pmic.200300815.

60. Steel LF, Trotter MG, Nakajima PB, Mattu TS, Gonye G, Block T. Efficient and specific removal of albumin from human serum samples. Mol Cell Proteomics. 2003. https://doi.org/10.1074/ mcp.M300026-MCP200.

61. EDQM Council of Europe. European Pharmacopoeia: 2.2.47 Kapillarelektrophorese. $10^{\text {th }}$ ed. Stuttgart: Deutscher Apotheker Verlag; 2020.
62. Kahle J, Maul KJ, Wätzig H. The next generation of capillary electrophoresis instruments: performance of CE-SDS protein analysis. Electrophoresis. 2018. https://doi.org/10.1002/elps. 201700278.

63. Meyer C, Seiler P, Bies C, Cianciulli C, Wätzig H, Meyer VR. Minimum required signal-to-noise ratio for optimal precision in HPLC and CE. Electrophoresis. 2012. https://doi.org/10.1002/ elps.201100694.

64. PerkinElmer, Inc. ProteinEXact HR Assay User Guide: For LabChip GXII Touch. PerkinElmer, Inc. 2021. https://www.perki nelmer.com/lab-solutions/resources/docs/BRO_ProteinEXactAssay_AG011808_22_BR.pdf. Accessed 8 Apr 2021.

65. Wiesner R, Scheller C, Krebs F, Wätzig H, Oltmann-Norden I. A comparative study of CE-SDS, SDS-PAGE, and Simple Western: influences of sample preparation on molecular weight determination of proteins. Electrophoresis. 2020. https://doi. org/10.1002/elps.202000199.

66. Porebski PÁ, Lynen F. Combining liquid chromatography with multiplexed capillary gel electrophoresis for offline comprehensive analysis of complex oligonucleotide samples. J Chromatogr A. 2014. https://doi.org/10.1016/j.chroma.2014.02.007.

67. PerkinElmer, Inc. Pico Protein Express Assay User Guide: For LabChip GXII Touch. PerkinElmer, Inc. 2019. https://www. perkinelmer.com/lab-solutions/resources/docs/GDE_Pico_Prote in_Express_User_Guide.pdf. Accessed 13 Jan 2021.

68. Issaq HJ, Chan KC, Janini GM, Muschik GM. A simple twodimensional high performance liquid chromatography/high performance capillary electrophoresis set-up for the separation of complex mixtures. Electrophoresis. 1999. https://doi.org/10. 1002/(SICI)1522-2683(19990601)20:7\%3c1533:AID-ELPS 1 $533 \% 3 \mathrm{e} 3.0 . \mathrm{CO} ; 2-\mathrm{V}$.

69. Murphy RE, Schure MR, Foley JP. Effect of sampling rate on resolution in comprehensive two-dimensional liquid chromatography. Anal Chem. 1998. https://doi.org/10.1021/ac971184b.

70. Davis JM, Stoll DR, Carr PW. Effect of first-dimension undersampling on effective peak capacity in comprehensive twodimensional separations. Anal Chem. 2008. https://doi.org/10. 1021/ac071504j.

71. Gu H, Huang Y, Carr PW. Peak capacity optimization in comprehensive two dimensional liquid chromatography: a practical approach. J Chromatogr A. 2011. https://doi.org/10.1016/j. chroma.2010.10.096.

72. Foley JP, Blackney DM, Ennis EJ. Peak capacity and peak capacity per unit time in capillary and microchip zone electrophoresis. J Chromatogr A. 2017. https://doi.org/10.1016/j. chroma.2017.08.043.

73. PerkinElmer, Inc. Low MW Protein Express Assay User Guide: For LabChip GXII Touch. Rev E; 2019.

74. Smith ER. The influence of method of preparation and of cations on the isoelectric point of ovalbumin. J Biol Chem. 1936. https://doi.org/10.1016/s0021-9258(18)74867-9.

75. Huopalahti R, Anton M, López-Fandiño R, Schade R. Bioactive egg compounds. Berlin, Heidelberg: Springer-Verlag, Berlin Heidelberg; 2007.

76. Brewer SH, Glomm WR, Johnson MC, Knag MK, Franzen S. Probing BSA binding to citrate-coated gold nanoparticles and surfaces. Langmuir. 2005. https://doi.org/10.1021/la050588t.

77. Hopwood D. Use of isoelectric focusing to determine the isoelectric point of bovine serum albumin after treatment with various common fixatives. Histochem J. 1971. https://doi.org/ 10.1007/BF01002564.

78. Carter DC, Ho JX. Structure of serum albumin. In: Lipoproteins, apolipoproteins, and lipases, vol. 45: Elsevier; 1994. pp. 153-203. 
79. CARLSSON HE, PERLMANN P. Isoelectric focusing and immunological characterization of human serum albumin. In: vol. 17: Elsevier; 1970. pp. 439-442.

80. Ul N. Isoelectric points and conformation of proteins. Biochimica et Biophysica Acta (BBA) - Protein Structure. 1971; https:// doi.org/10.1016/0005-2795(71)90272-8

81. Lemma T, Pawliszyn J. Human serum albumin interaction with oxaliplatin studied by capillary isoelectric focusing with the whole column imaging detection and spectroscopic method. J Pharm Biomed Anal. 2009. https://doi.org/10.1016/j.jpba.2008. 10.028 .

82. Jones OG, Handschin S, Adamcik J, Harnau L, Bolisetty S, Mezzenga R. Complexation of $\beta$-lactoglobulin fibrils and sulfated polysaccharides. Biomacromol. 2011. https://doi.org/10. 1021/bm200686r.

83. Fox PF, Uniacke-Lowe T, McSweeney PLH, O'Mahony JA. Dairy Chemistry and Biochemistry. $2^{\text {nd }}$ ed. 2015. s.l.: SpringerVerlag; 2015.
84. Hallgren E, Kálmán F, Farnan D, Horváth C, Ståhlberg J. Protein retention in ion-exchange chromatography: effect of net charge and charge distribution. J Chromatogr A. 2000. https:// doi.org/10.1016/S0021-9673(00)00190-4.

85. Kopaciewicz W, Rounds MA, Fausnaugh J, Regnier FE. Retention model for high-performance ion-exchange chromatography. J Chromatogr A. 1983. https://doi.org/10.1016/S0021-9673(01) 90875-1.

Publisher's note Springer Nature remains neutral with regard to jurisdictional claims in published maps and institutional affiliations. 